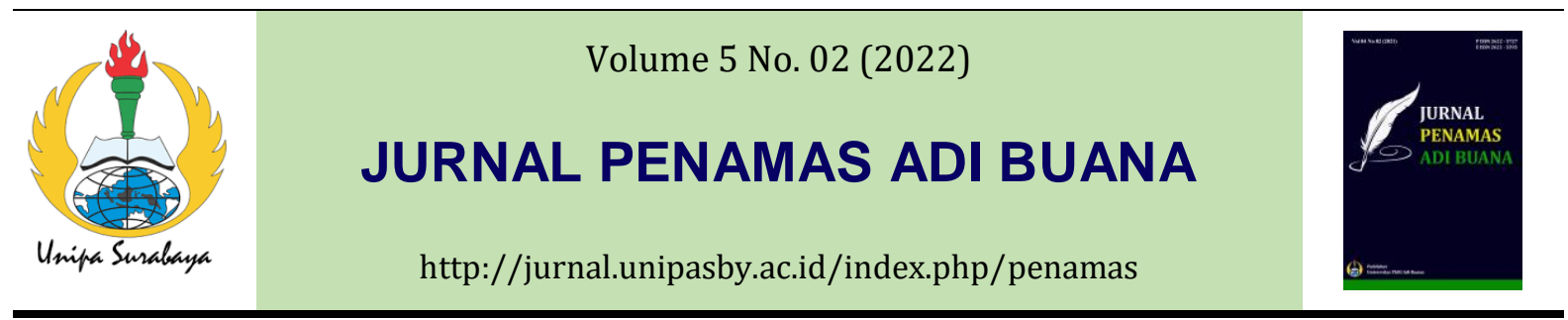

\title{
PELATIHAN PEMBUATAN SIOMAY BERBAHAN DASAR IKAN LELE UNTUK GURU DAN SISWA SMA WIJAYA PUTRA SURABAYA
}

\author{
Purity Sabila Ajiningrum $^{1}$, Diah Karunia Binawati ${ }^{1}$, Ngadiani $^{1}$, Vivin Andriani ${ }^{1}$, \\ Sukarjati $^{1}$, Susie Amilah ${ }^{1}$ \\ ${ }^{1}$ Program Studi Biologi, Fakultas Sains dan Tehnologi, Universitas PGRI Adi Buana Surabaya, Surabaya, \\ Indonesia \\ *Email: puritysabila@unipasby.ac.id
}

\begin{tabular}{ll}
\hline Informasi Artikel & Abstrak \\
\hline Kata kunci: & $\begin{array}{l}\text { Ikan lele merupakan salah satu jenis ikan konsumsi yang bernilai ekonomis } \\
\text { tinggi sehingga banyak dimanfaatkan masyarakat untuk dijadikan produk } \\
\text { olahan. Olahan ikan lele salah satunya adalah dapat dibuat sebagai bahan } \\
\text { dasar pembuatan siomay. Pelatihan membuat olahan pangan berbahan dasar }\end{array}$ \\
$\begin{array}{l}\text { Lele, pengabdian } \\
\text { kepada masyarakat, } \\
\text { olahan pangan, siomay }\end{array}$ & $\begin{array}{l}\text { dimanfaatkan sebagai alternatif pangan dan dapat digunakan untuk } \\
\text { berwirausaha sehingga memperoleh tambahan pendapatan. Metode yang }\end{array}$ \\
Diterima: 16-10-2021 & $\begin{array}{l}\text { digunakan dalam pelatihan ini yaitu menggunakan virtual web conference. } \\
\text { kerdasarkan hasil kuesioner didapatkan hasil sebesar 83,4\% tentang }\end{array}$ \\
Disetujui: 22-01-2022 & $\begin{array}{l}\text { kejelasan narasumber dalam memberikan informasi, persentase kejelasan } \\
\text { gambar yang diterima mitra saat narasumber melakukan zoom cloud }\end{array}$ \\
Dipubikasikan: 31-01- & $\begin{array}{l}\text { meeting sebesar 80\% baik dan sebesar 20\% mitra yang menyatakan } \\
\text { kejelasan gambar yang kurang bagus. Hasil evaluasi setelah berlangsungnya } \\
\text { kegiatan dianalisis dari hasil pretest yang mana ternyata kurang dari 40\% }\end{array}$ \\
& $\begin{array}{l}\text { mitra belum mengetahui tentang pengolahan daging ikan lele menjadi } \\
\text { siomay, namun dari hasil post test pada akhir kegiatan, 87\% mitra akhirnya } \\
\text { mengetahui bagaimana cara membuat siomay dari daging ikan lele. }\end{array}$
\end{tabular}

\section{Abstract}

\section{Keywords:}

Catfish, Community Service Programme, processing food, dumplings

Catfish is one type of consumption fish that has high economic value so that it is widely used by the community to be used as processed products. One of the processed catfishes is that it can be made as a basic ingredient for making dumplings. Training on making processed food made from catfish aimed at teachers and students of SMA Wijaya Putra can be used as an alternative food and also can be used for entrepreneurship so as to obtain additional income. The method used in this training is virtual web conference. Based on the results of the questionnaire, the results were $83,4 \%$ regarding the clarity of the resource persons in providing information, the percentage of image clarity received by partners when the resource persons made presentations was $80 \%$ good and $20 \%$ of partners stated that the clarity of the images was not good. The results of the evaluation after the activity were analyzed from the results of the pretest which turned out to be less than $40 \%$ of partners did not know about processing catfish meat into dumplings, but from the post test results at the 
end of the activity, $87 \%$ of partners finally knew how to make dumplings from catfish meat.

\section{PENDAHULUAN}

Ikan lele merupakan salah satu jenis ikan konsumsi yang bernilai ekonomis tinggi sehingga banyak dimanfaatkan masyarakat untuk dijadikan produk olahan (Widyaningrum, 2017). Ikan lele mempunyai kandungan gizi, khususnya protein yang sangat bermanfaat untuk kesehatan (Rahayu, et al, 2019). Protein berfungsi untuk pertumbuhan, mengganti jaringan yang rusak dan meningkatkan daya tahan tubuh terhadap serangan penyakit. Selain mengandung protein, ikan lele mengandung asam lemak tak jenuh yang bermanfaat untuk menangkal terjadinya serangan jantung.

Olahan daging ikan lele dapat dimanfaatkan sebagai salah satu bahan dasar siomay. Siomay adalah jenis makanan ringan yang dibuat dari adonan daging ayam cincang dan tepung tapioka dicampur bumbu-bumbu dan bahan penyedap yang kemudian dibungkus dengan kulit pangsit, dengan bagian atas dibiarkan terbuka. Kulit pangsit adalah adonan telur dan tepung terigu, berbentuk kotak atau bundar, yang kemudian difungsikan sebagai pembungkus adonan yang lain (). Siomay dapat dikonsumsi sendiri dengan dicocol saus sambal, atau sebagai pelengkap bakso dan atau siomay bandung. Cara penyajiannya pun bermacam-macam. Ada yang cukup dikukus begitu saja, diberi kuah atau digoreng, bergantung selera yang mengkonsumsi (Hanafie et al., 2018). Siomay lele dapat langsung dikonsumsi atau disimpan dalam kondisi beku (frozen) dengan batasan waktu tertentu, antara lain tergantung pada temperatur penyimpanan, kebersihan wadah penyimpanan, proses pemasakan dan bahan baku produk tersebut. Setiap produk olahan mempunyai standar baku untuk menjaga kualitas produk disamping untuk melindungi konsumen dari dampak buruk produk yang berbahaya terhadap keamanan (Pudjirahayu, 2018).

Pada pelatihan ini akan dijelaskan teknik pemilihan bahan baku segar dan bagaimana mengolah daging ikan lele menjadi siomay yang lezat dan bergizi. Pelatihan membuat olahan pangan berbahan dasar ikan lele yang ditujukan kepada guru dan siswa SMA Wijaya Putra selain dapat dimanfaatkan sebagai alternatif pangan untuk dicoba dirumah, dalam kondisi pandemi seperti saat ini diharapkan dapat menimbulkan semangat berwirausaha bagi para guru dan siswa sehingga memperoleh tambahan pendapatan.

\section{METODE}

Peserta program pengabdian kepada masyarakat Prodi Biologi FST UNIPA berasal dari guru dan siswa SMA Wijaya Putra Surabaya. Metode dan tahap pelaksanaan kegiatan ini meliputi:

1. Metode pelaksanaan secara virtual

Semakin pesatnya perkembangan ilmu pengetahuan berdampak positif terhadap perkembangan teknologi virtual digital pada dunia pendidikan, ekonomi, kesehatan dan lainnya (Putra, 2018). Pada program pengabdian berlangsung pada saat Pandemi Covid-19 maka penerapan social 
distancing dilakukan dengan cara berkomunikasi dengan peserta pengabdian menggunakan media zoom cloud meeting. Aplikasi tersebut merupakan salah satu jenis metode virtual simulasi dengan menggunakan platform virtual web conferencing (Verkuyl et al., 2018), sehingga pelaksanaan kegiatan pengabdian ini lebih efektif, efisien dan aman dalam masa pandemi.

2. Tahap Pelaksanaan Kegiatan:

a. Survey dan pengurusan surat ijin

Tujuan pada kegiatan ini adalah untuk mencari informasi dan pengurusan perijinan pelaksanaan.

b. Sosialisasi

Sosialisasi kegiatan dilakukan kepada Kepala Sekolah SMA Wijaya Putra yaitu menjelaskan bagaimana kegiatan akan dilakukan melalui aplikasi zoom cloud meeting.

c. Pelaksanaan Kegiatan

Pelaksanaan kegiatan meliputi mempersiapkan tempat dan sarana yang akan digunakan pada waktu kegiatan, mempersiapakan jadwal kegiatan dan materi yang akan disampaikan, mempersiapkan video praktek pembuatan siomay ikan lele, persiapan peserta dengan mengingatkan untuk bergabung dalan aplikasi zoom dan penyampaian materi.

d. Evaluasi Kegiatan

Bentuk evaluasi dari kegiatan pengabdian ini adalah dengan pengisian beberapa pertanyaan yang disediakan pada google formulir.

\section{HASIL DAN PEMBAHASAN}

Pelatihan membuat olahan pangan berbahan dasar ikan lele yang ditujukan ke para guru dan siswa SMA Wijaya Putra dapat dimanfaatkan guna meningkatkan pengetahuan dan keterampilan tentang produk olahan berbahan baku ikan lele. Ikan Lele mudah didapat dan sebagian besar masyarakat mengenal ikan Lele. Pada saat ini pemanfaatan ikan lele pada umumnya hanya sebatas dikonsumsi langsung tanpa diolah. Diversifikasi atau penganekaragaman produk olahan hasil perikanan merupakan pengembangan produk hasil perikanan sehingga mampu memberikan nilai tambah, baik olahan tradisional maupun modern guna mengoptimalkan pemanfaatan produksi hasil perikanan (Agustini \& Swastawati, 2003).

Kegiatan pertama yang dilakukan yaitu menjelaskan tentang materi diversifikasi produk olahan pangan berbahan dasar ikan lele. Materi yang diberikan meliputi kandungan gizi siomay lele dan cara membuat siomay lele yang disajikan dalam bentuk video. Video materi pembuatan siomay lele meliputi tahapan pelaksanaan kegiatan seperti persiapan peralatan, persiapan bahan pembuatan siomay lele dan langkah-langkah membuat siomay lele. 

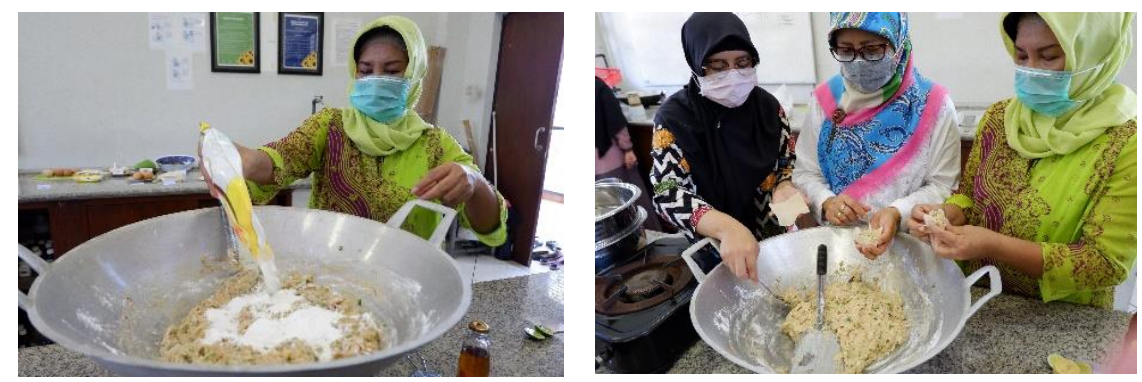

Gambar 1. Proses pembuatan siomay lele

Selanjutnya, setelah pemutaran video pembuatan siomay selesai, moderator membuka sesi tanya jawab kepada peserta. Peserta memberikan pertanyaan mengenai bagaimana memilih ikan lele yang baik dan segar agar dapat digunakan untuk membuat siomay. Pada dasarnya hampir semua jenis ikan dan hasil perikanan lainnya, dapat dimanfaatkan dagingnya untuk membuat siomay ikan. Ikan Nila, lele, gurame, tongkol, udang, kepiting dan jenis-jenis lainnya dapat diolah menjadi siomay. Prinsip yang sangat penting yang harus diperhatikan dalam memilih ikan sebagai bahan dasar pembuatan nugget adalah ikan harus segar, tidak cacat fisik dan berkualitas baik. Ikan yang segar memiliki mutu/kualitas protein masih tinggi, serta kapasitas mengikat airnya (water holding capacity) masih baik.

Kesegaran ikan dapat diketahui dengan cara mengamati penampilan fisik, mata, insang, tekstur dan baunya. Ikan segar tampak mengkilap sesuai jenis ikan. Lendir di permukaan tubuh tidak ada, kalau ada hanya tipis dan bening. Sisik menempel kuat dan tidak mudah lepas, perut utuh dan lubang annus tertutup. Mata cembung, cerah, putih jernih, pupil hitam dan tidak berdarah. Insang merah cerah dan tidak berlendir atau sedikit lendir. Tekstur daging kenyal, lentur dan berbau segar atau sedikit amis.
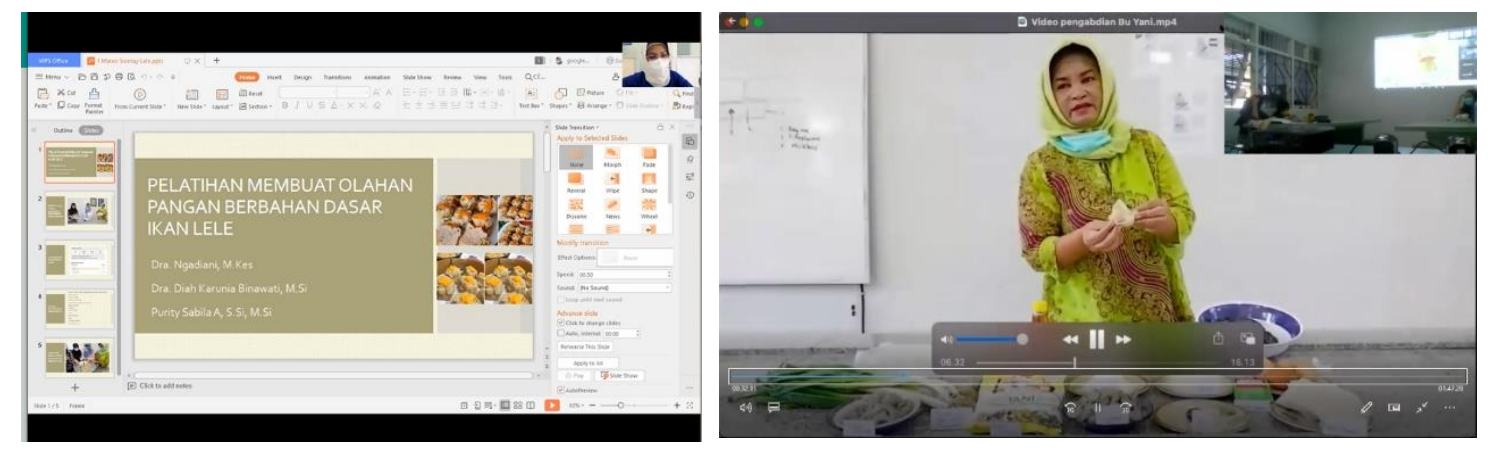

Gambar 2. Presentasi materi secara daring dan pemutaran video

Berdasarkan penyampaian tentang bagaimana mengolah ikan lele dan membuat siomay, hasil kuesioner tentang kejelasan narasumber dalam memberikan informasi memiliki persentase sebesar 
83,4\%. Mitra memberikan pernyataan bahwa materi yang disampaikan oleh narasumber dan bahasa yang digunakan saat penyampaian materi dapat diterima. Poin selanjutnya yaitu persentase kejelasan gambar yang diterima mitra saat narasumber melakukan zoom cloud meeting sebesar $80 \%$ baik dan sebesar 20\% mitra yang menyatakan kejelasan gambar yang kurang bagus. Hal ini disebabkan adanya kendala jaringan internet yang kurang baik ketika pelaksanaan. Hasil evaluasi setelah berlangsungnya kegiatan dianalisis dari hasil pretest yang mana ternyata kurang dari $40 \%$ mitra belum mengetahui tentang pengolahan daging ikan lele menjadi siomay, namun dari hasil post test pada akhir kegiatan, $87 \%$ mitra akhirnya mengetahui bagaimana cara membuat siomay dari daging ikan lele.

\section{KESIMPULAN}

Kegiatan pengabdian ini dilaksanakan secara daring dengan menggunakan aplikasi zoom cloud meeting. Kegiatan pengabdian ini dapat menambah pengetahuan guru dan siswa SMA Wijaya Putra Surabaya mengenai bagaimana mengolah ikan lele dan membuat siomay sebesar $87 \%$. Pada kegiatan pengabdian masyarakat yang akan datang, tim pengabdian akan mencoba untuk melakukan praktek secara langsung (tatap muka) dan memberikan penjelasan mengenai bagaimana cara pengemasan produk yang baik dan benar.

\section{UCAPAN TERIMAKASIH}

Penulis mengucapkan terima kasih kepada Universitas PGRI Adi Buana Surabaya yang telah memberi dukungan dana terhadap kegiatan pengabdian kepada masyarakat ini.

\section{DAFTAR PUSTAKA}

Agustini, T.W, \& Swastawati, F. 2003. Pemanfaatan Hasil Perikanan Sebagai Produk Bernilai Tambah (Value-Added) Dalam Upaya Penganekaragaman Pangan'. Jurnal Teknol. Dan Industri Pangan, XIV(1), 74-81.

Hanafie, S.R.J., \& Nugroho, I. (2018). Industri Rumah Tangga Siomay di Kota Malang. Conference on Inovation and Application of Science and Technology (CIASTECH 2018). 281-286.

Putra, R. A. (2018). Peran Teknologi Digital Dalam Perkembangan Dunia Perancangan Arsitektur R. Elkawnie: Journal of Islamic Science and Technology, 4(1), 67-78. www.jurnal.arraniry.com/index.php/elkawnie

Pudjiastutik, A. (2018). Bahan Ajar Gizi: Pengawasan Mutu Pangan. http://bppsdmk.kemkes.go.id/pusdiksdmk/wp-content/uploads/2018/05/Pengawasan-MutuPangan SC.pdf

Rahayu, D.U.S., Piranti, A.S, \& Sihwaningrum. (2019). Diversifikasi Hasil Olahan Ikan Lele di Desa Kaliwangi Kecamatan Purwojati, Kabupaten Banyumas. Dinamika Journal, 1(1), 54-61.

Widyaningrum, R. (2017). Penerapan Sanitasi Pada Produksi Siomay Ikan Lele Dumbo (Clarias Gariepinus) Di Pusat Pelatihan Mandiri Kelautan Dan Perikanan (P2mkp) Karya Lestari, Kabupaten Tabanan, Provinsi Bali. https://repository.unair.ac.id/77643/

Verkuyl, M., Atack, L., McCulloch, T., Liu, L., Betts, L., Lapum, J. L., Hughes, M., Mastrilli, P., \& Romaniuk, D. (2018). Comparison of Debriefing Methods after a Virtual Simulation: An Experiment. Clinical Simulation in Nursing, 19, 1-7. https://doi.org/10.1016/j.ecns.2018.03.02 